\title{
Prevalence and distribution of soil-transmitted helminth infections in Nigerian children: a systematic review and meta-analysis
}

\author{
Solomon Ngutor Karshima®
}

\begin{abstract}
Background: Soil transmitted helminth (STH) infections still remain a notable health problem in resource-limited countries due to difficulties in the implementation of control measures. In Nigeria for instance, despite several community-based and provincial reports, national data on prevalence, burdens and risk zones (RZs) for STH infections are lacking.

Methods: The present study employed the recommendations of the Preferred Reporting Items for Systematic Reviews and Meta-Analyses (PRISMA) to determine the prevalence, distribution and RZs for STH infections among Nigerian children through a meta-analysis of data published between 1980 and 2015. Pooled prevalence estimate (PPE) was determined by the random-effects model while heterogeneity was evaluated using the Cochran's Q-test.

Results: A total of 18901 of the 34518 Nigerian children aged 0-17 years examined across 19 Nigerian states during the period under review were infected with one or more species of STHs. The overall PPE for STH infections was 54.8\% (95\% Cl: 54.2-55.3). PPEs for sub-groups ranged between 13.2\% (95\% Cl: 11.5-15.1) and 80.9\% (95\% Cl: 80.0-81.7). Highest PPEs for STH infections were observed among children within community settings $(59.0 \%$, 95\% Cl: 57.7-60.4) and school-aged children (54.9\%, 95\% Cl: 54.3-55.5). Ascaris lumbricoides was the most prevalent species (44.6\%, 95\% Cl: 44.0-45.2). Over 36\% (15/41) of the studies were published from south-western Nigeria. South-western region was the only high risk zone (HRZ) for STH infections while the rest of the regions were low risk zones (LRZs).

Conclusions: STH infections involving Ascaris lumbricoides, Strongyloides stercoralis, Trichuris trichiura and hookworms are highly prevalent across Nigeria. Strategic use of anthelmintics, health education and adequate sanitation, taking into account this epidemiologic information will help in the control of these infections in Nigeria.
\end{abstract}

Keywords: Children, Distribution, Nigeria, Prevalence, Soil-transmitted helminth infections, Risk zones

\section{Multilingual abstract}

Please see Additional file 1 for translations of the abstract into the five official working languages of the United Nations

\section{Background}

Soil-transmitted helminths are among the leading causes of global health problems especially among the poorest and deprived communities where implementation of

Correspondence: torkarshima@yahoo.co.uk

Department of Veterinary Public Health and Preventive Medicine, University of Jos, PMB 2084, Jos, Nigeria

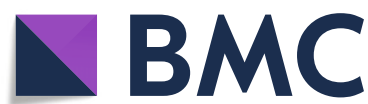

control measures is difficult [1,2]. Globally, over one billion people are infected by at least one of the commonest species namely: Ascaris lumbricoides (the roundworm), Trichuris trichiura (the whipworm) Strongyloides stercoralis (threadworm) and the hookworms; Ancylostoma duodenale and Necator americanus [3].

Environmental survival of STH eggs and larvae including hatching and embryonation are determined by warm temperatures and adequate moisture [4]. Human infection is influenced by poverty, poor personal hygiene, inadequate sanitation and overcrowding $[5,6]$. Infections may result in anaemia, retarded growth, and impaired

(c) The Author(s). 2018 Open Access This article is distributed under the terms of the Creative Commons Attribution 4.0 International License (http://creativecommons.org/licenses/by/4.0/), which permits unrestricted use, distribution, and reproduction in any medium, provided you give appropriate credit to the original author(s) and the source, provide a link to the Creative Commons license, and indicate if changes were made. The Creative Commons Public Domain Dedication waiver (http://creativecommons.org/publicdomain/zero/1.0/) applies to the data made available in this article, unless otherwise stated. 
cognitive development [7] and are classified among the major causes of absenteeism and disability adjusted life years lost [8].

Substantive evidence suggests that the most vulnerable group are children $[4,9]$ where infections are acquired through playing with contaminated soil and pica habits $[10,11]$. Despite global decline in the prevalence of $A$. lumbricoides, T. trichiura and the hookworms (A. duodenale and $N$. americanus) in the Americas and Asia, the situation in sub-Saharan Africa remains stagnant [12].

According to the World Health Organization (WHO), administration of drugs like albendazole and mebendazole, health education and adequate sanitation are central to the control of STH infections. Community-based strategic drug administration which is vital to the control of STH infections requires epidemiological assessment and disease prevalence in communities as guides for choosing and instituting treatments [13].

Published literature on the prevalence of STH infections in Nigeria dates back to the 1970s [14]. However, there is no evidence of national control programmes despite advocacies for improved sanitation, health education and targeted chemotherapy in high risk communities to reduce the burden of these infections in Nigeria [15-18]. For instance, there have been some sporadic and uncoordinated deworming programmes, mostly sponsored by few politicians and philanthropists.

Recent STH control programmes focus on mass drug administration (MDA) in endemic regions to reduce parasite burdens and their effects $[19,20]$. The successes and cost-effectiveness of these MDA programmes depend on the knowledge of STH prevalence which is used to classify communities into high or low RZs. In a resource-limited country like Nigeria, with a population of over 190 million people, cost-effectiveness in the control of STH infections is essential to ensure efficient allocation of resources and achievement of high impact. Hence, the aim of this meta-analysis which is the first of its kind in Nigeria was to provide useful epidemiological information including endemic species of STHs, their prevalence, distribution and RZs in Nigeria. This will serve as a guide for targeted control and ensure cost effective control of STH infections in Nigeria.

\section{Methods}

\section{Country profile}

Studies included in this meta-analysis were carried out in Nigeria; a country with a population of over 190 million people which covers a surface area of $923768 \mathrm{~km}^{2}$ in the sub-Saharan African region (Fig. 1). It has two distinct seasons; the rainy season which runs from March to November in the southern region and May to October in the northern region as well as the dry season which runs from December to February in the south and November to April in the North [21].

\section{Bibliography search strategy}

The present study followed the PRISMA guidelines published by Moher et al. [22]. The study conducted a systematic review to identify studies that reported the prevalence of STH infections in Nigerian children. Data from suitable studies were then meta-analysed to determine pooled prevalence estimates (PPEs), distribution and RZs of STHs in Nigeria. Inclusion of information in the study was guided by the PRISMA checklist (Additional file 2). The outcome of interest was the presence of STH infections in Nigerian children.

Published studies were searched in four databases (PubMed, Google Scholars, Medline, AJOL) and lists of references of retrieved articles between September 2016 and March 2017. For clarity and ease of understanding and interpretation of contents, only studies published in English which is the official language in Nigeria, were included in the analysis. Because children are the most vulnerable group targeted by majority of STHs control programmes, selection process was restricted to studies carried out on children. To ensure that data included in the analysis were creditable and of good quality, only data published in reputable journals indexed at least in African Journals Online were included in the study. Since it was one of the objectives of the study to determine the prevalence and distribution of STH infections across Nigeria, study selection was restricted to studies with clearly stated sample sizes, number of positive samples and study locations.

Keywords employed for the literature search were: Prevalence/occurrence of soil-transmitted helminths/geo-helminths in Nigerian children. Common names of soil-transmitted helminths such as roundworm, whipworm, threadworm and hookworms were also used. Genera and species names for STHs of humans such as Ascaris \pm lumbricoides, Strongyloides \pm stercoralis, Trichuris \pm trichiura, Ancylostoma \pm duodenale, Necator \pm americanus were also employed. Searches were narrowed down to regions like the north-central, north-east, north-west, south-east, south-south, south-west and the 36 states of the Nigerian federation.

\section{Criteria for inclusion and exclusion of studies}

Studies were first screened through title review for relevance and removal of duplicates. This was followed by a detailed abstract and full text review to determine the presence of the outcome of interest and other inclusion requirements. Eligibility for inclusion of a study was based on the following conditions: (i) it was carried out in Nigeria, (ii) it was published in English, (iii) it was a cross sectional study, (iv) study location was clearly 


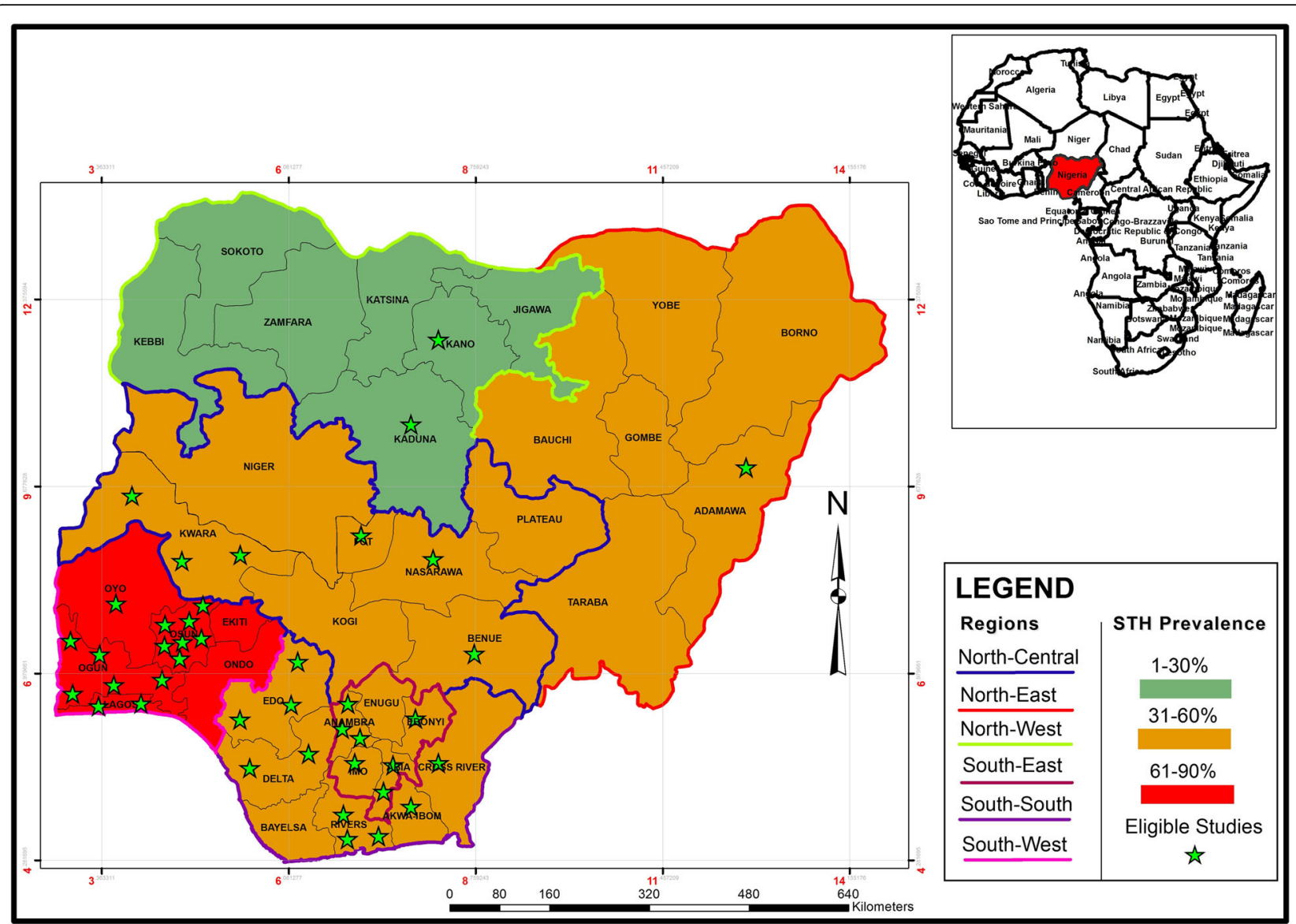

Fig. 1 Study areas, regional prevalence and distribution of eligible studies

stated, (v) sample size and number of positive cases were clearly stated, (vi) it was published in a reputable journal indexed at least in African Journal Online, (vii) it reported STH infections in Nigerian children, (viii) parasites were identified at least to the genus level with the exception of hookworms. All the studies included in the analysis were assessed for quality independently using the Newcastle-Ottawa Scale according to the Cochrane Handbook for Systematic Reviews [23, 24].

\section{Data extraction}

Data extracted from the eligible studies were: surname of first author, year of conduct and publication of study, sample size, number of positives cases, state and region of study, study design, species of STHs identified at least to the genus level.

\section{Data collation and analysis}

Data were first entered through Microsoft Excel version 2007 (MS Corporation, Washington, USA) and further subjected to Graph-Pad Prism version 4.0 (Graph-Pad Software, San Diego, USA) and Comprehensive Meta-Analysis version 3.0 (Biostat, Englewood, USA) for statistical and meta-analysis respectively. Prevalence for individual studies was determined by multiplying the ratio of cases to sample size by 100 . The $95 \%$ Confidence Interval $(95 \% C I)$ was determined using the exact binomial interval (http://statpages.info/confint.html). Based on the assumption that true effect sizes might differ within eligible studies, the random-effects model was used to determine PPEs and their $95 \% C I$ [25]. Heterogeneity, which is the measure of variability between studies analysed was evaluated using the Cochran's Q-test while percentage variation in prevalence estimate due to heterogeneity was quantified using the formula $I^{2}=100 \times(\mathrm{Q}-\mathrm{df}) / \mathrm{Q}$, where $\mathrm{Q}$ is Cochran's heterogeneity statistic and $d f$ is the degree of freedom which is the difference between the number of studies and one. $I$-square values of $0,25,50$ and $75 \%$ were considered as no, low, moderate and high heterogeneities respectively [26]. RZs for STH infections were categorized based on prevalence of infections as recommended by the WHO. Regions with PPEs $\leq 20 \%$ to $<50 \%$ were classified as LRZs while regions with PPEs $\geq 50$ were classified as HRZs for STH infections [27]. 


\section{Results}

Literature search and eligible studies

The selection process for eligible studies is presented in Fig. 2. Of the 94 studies retrieved, 79 and 15 were generated through the search of databases and lists of references of articles respectively. Thirty eight duplicate studies were removed after the screening of titles. Fifty six studies were further subjected to abstract and full text review where 15 studies were excluded for the following reasons: unstated numbers of positive samples and sample sizes $(n=4)$ and quality of publishing journals $(n=11)$.

\section{Characteristics of the eligible studies}

Table 1 presents the characteristics of the studies meta-analysed. Forty one studies were eligible and thus were included in the analysis. Studies were conducted between 1980 and 2014 and published between 1981 and 2015. Four, seven and 30 of the studies were carried out between 1980 and 1991, 1992 and 2003 as well as 2004 and 2014 respectively. One, two, six, seven, 11 and 14 of the studies were reported from north-east, north-west, north-central, south-east, south-south and south-west Nigeria respectively. Two, nine and 30 studies were carried out within hospital, community and school settings respectively. Five, six, seven and 23 of the studies had sample sizes of greater than 1500, 501-1000, 1001-1500 and 100-500 respectively. Thirty three studies were reported among school-aged children while 8 of the studies were reported among pre-school-aged children. Prevalence of STH infections among eligible studies ranged between 6.0 and $96.1 \%$.

\section{Pooled prevalence estimates and heterogeneity analysis}

Overall and sub-group PPEs for STH infections are presented in Table 2. A total of 18901 of the 34518 Nigerian children examined during the period under review were infected with one or more species of STHs yielding an overall PPE of 54.8\% (95\% CI: 54.2-55.3). PPEs for sub-groups (regions, study period, sample size, study settings and school/preschool-aged children) ranged between 13.2\% (95\% CI: 11.5-15.1) and 80.9\% (95\% CI: 80.0-81.7). A high degree of heterogeneity $99.4 \%$ (95\% CI: 54.2-5.3, $P<0.0001)$ was observed within studies and sub-groups (Figs. 3, 4, 5, 6 and 7 and Additional files 3, 4 and 5).

A. lumbricoides had the highest PPE of $44.6 \%$ (95\% CI: 44.0-45.2) while, T. trichiura, hookworms and S. stercoralis recorded PPEs of 31.9\% (95\% CI: 31.3-32.5), 23.0\% (95\% CI: 22.5-23.5) and 3.4\% (95\% CI: 3.1-3.8) respectively (Table 3). A. lumbricoides (53.9\%) and T. trichiura

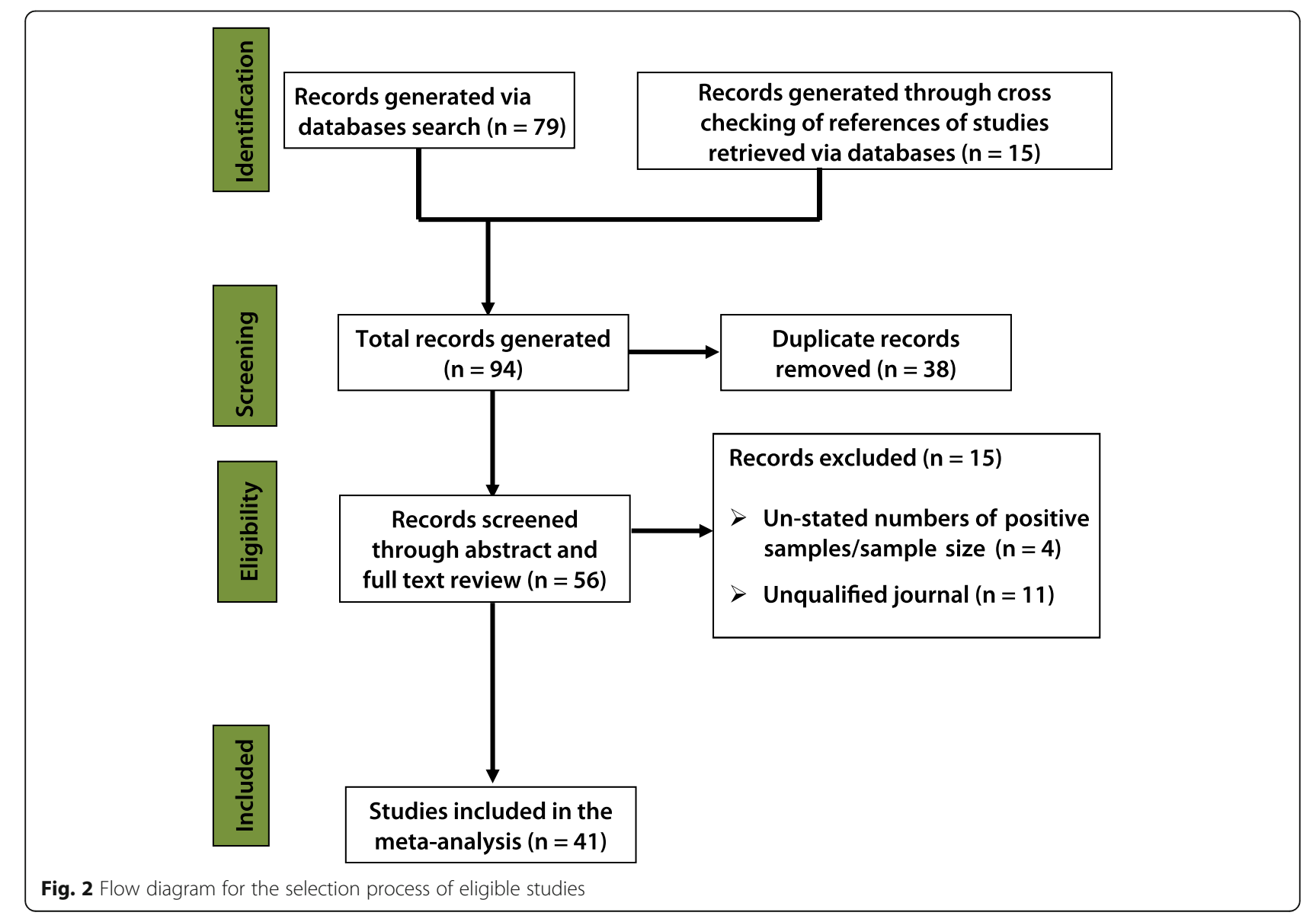


Table 1 List and characteristics of the 41 eligible studies

\begin{tabular}{|c|c|c|c|c|c|c|c|c|}
\hline Study ID & Year of study & State & Region & Study setting & Sample size & Cases & Prevalence (\%) & $95 \% \mathrm{Cl}$ \\
\hline [57] & 2011 & Rivers & SSR & School-based & 3826 & 1050 & 27.4 & $26.0-28.9$ \\
\hline [58] & $2012 / 2013$ & Kwara & NCR & School-based & 1017 & 229 & 22.5 & $20.0-25.2$ \\
\hline [59] & 1989 & Kwara & NCR & Community-based & 907 & 797 & 87.9 & $85.6-89.9$ \\
\hline$[60]$ & 2002 & Ogun & SWR & School-based & 1253 & 1129 & 90.1 & $88.3-91.7$ \\
\hline [61] & 2006 & Lagos & SWR & School-based & 1177 & 579 & 49.2 & $46.3-52.1$ \\
\hline [62] & $2005 / 2006$ & Ogun & SWR & School-based & 1059 & 872 & 82.3 & $79.9-84.6$ \\
\hline [63] & 2007 & Cross River & SSR & Community-based & 350 & 174 & 49.7 & $44.4-55.1$ \\
\hline [64] & 1985 & Rivers & SSR & Community-based & 1062 & 1020 & 96.1 & $94.7-97.1$ \\
\hline [65] & 2011 & Anambra & SER & School-based & 200 & 80 & 40.0 & $33.2-47.2$ \\
\hline [66] & 2014 & Kwara & NCR & School-based & 304 & 54 & 17.8 & $13.6-22.5$ \\
\hline [67] & 1980 & Lagos & SWR & School-based & 5595 & 4241 & 75.8 & $74.7-76.9$ \\
\hline [68] & 2008 & Nasarawa & NCR & School-based & 480 & 314 & 65.4 & $61.0-69.7$ \\
\hline [69] & $2004 / 2005$ & Ogun & SWR & School-based & 232 & 112 & 48.3 & $41.7-54.9$ \\
\hline [70] & 1993 & Anambra & SER & School-based & 1536 & 775 & 50.5 & $47.9-53.0$ \\
\hline [71] & 1987 & Oyo & SWR & School-based & 766 & 678 & 88.5 & $86.0-90.7$ \\
\hline [72] & 2012 & Kano & NWR & School-based & 570 & 95 & 16.7 & $13.7-20.0$ \\
\hline [73] & 2005 & Osun & SWR & Community-based & 369 & 48 & 13.0 & $9.8-16.9$ \\
\hline [74] & $2006 / 2007$ & Osun & SWR & Community-based & 1228 & 684 & 55.7 & $52.9-58.5$ \\
\hline$[75]$ & $2005 / 2006$ & Delta & SSR & School-based & 1200 & 960 & 80.0 & $77.6-82.2$ \\
\hline$[76]$ & 2002 & Kaduna & NWR & School-based & 800 & 86 & 10.8 & $8.7-13.1$ \\
\hline [77] & 2011 & Abuja & NCR & School-based & 220 & 90 & 40.9 & $34.4-47.7$ \\
\hline [78] & 2011 & Edo & SSR & Community-based & 140 & 29 & 20.7 & $14.3-28.4$ \\
\hline [79] & $2008 / 2009$ & Edo & SSR & Hospital-based & 310 & 170 & 54.8 & $49.1-60.5$ \\
\hline [80] & 2012 & Delta & SSR & School-based & 200 & 117 & 58.5 & $51.3-65.4$ \\
\hline [81] & 2007 & Anambra & SER & School-based & 514 & 275 & 53.5 & $49.1-57.9$ \\
\hline [82] & 2012 & Imo & SER & School-based & 284 & 88 & 31.0 & $25.7-36.7$ \\
\hline [83] & 2000 & Osun & SWR & School-based & 749 & 245 & 32.7 & $29.4-36.2$ \\
\hline [84] & 2009 & Akwa Ibom & SSR & School-based & 405 & 286 & 70.6 & $65.9-75.0$ \\
\hline [85] & 2005 & Adamawa & NER & School-based & 250 & 114 & 45.6 & $39.3-52.0$ \\
\hline [86] & 2013 & Abia & SER & School-based & 200 & 41 & 20.5 & $15.1-26.8$ \\
\hline [87] & 2003 & Ogun & SWR & School-based & 2837 & 1376 & 48.5 & $46.7-50.4$ \\
\hline [88] & 2003-2005 & Ogun & SWR & School-based & 1519 & 435 & 28.6 & $26.4-31.0$ \\
\hline [89] & 2009 & Osun & SWR & Community-based & 352 & 121 & 34.4 & $29.4-39.6$ \\
\hline [90] & 2005 & Osun & SWR & Community-based & 300 & 18 & 6.0 & $3.6-9.3$ \\
\hline [91] & 2012 & Ebonyi & SER & School-based & 300 & 244 & 81.3 & $76.5-85.6$ \\
\hline [92] & $2004 / 2005$ & Osun & SWR & School-based & 489 & 468 & 95.7 & $93.5-97.3$ \\
\hline [93] & 2011 & Osun & SWR & School-based & 419 & 401 & 95.7 & $93.3-97.4$ \\
\hline [94] & 2002 & Abia & SER & School-based & 300 & 277 & 92.3 & $88.7-95.1$ \\
\hline [95] & 2014 & Benue & $N C R$ & Community-based & 228 & 23 & 10.1 & $6.5-14.8$ \\
\hline [96] & $2001 / 2002$ & Edo & SSR & Hospital-based & 207 & 44 & 21.3 & $15.9-27.5$ \\
\hline [97] & 2013 & Rivers & SSR & School-based & 364 & 62 & 17.0 & $13.3-21.3$ \\
\hline
\end{tabular}


Table 2 Pooled prevalence estimates for STH infections in Nigerian children stratified according to sub-groups

\begin{tabular}{|c|c|c|c|c|c|c|c|}
\hline \multirow[t]{2}{*}{ Variables } & \multirow{2}{*}{$\begin{array}{l}\text { No. of } \\
\text { studies }\end{array}$} & \multicolumn{3}{|c|}{ Pooled prevalence estimates } & \multirow[t]{2}{*}{$95 \% \mathrm{Cl}$} & \multicolumn{2}{|c|}{ Heterogeneity } \\
\hline & & Sample size & Positives & Prevalence (\%) & & $\overline{P(\%)}$ & $\mathrm{Q}-\mathrm{P}$ \\
\hline \multicolumn{8}{|l|}{ Region } \\
\hline North-central & 6 & 3156 & 1507 & 47.8 & $46.0-49.5$ & 99.4 & 0.000 \\
\hline North-east & 1 & 250 & 114 & 45.6 & $39.3-52.0$ & 0.0 & 0.000 \\
\hline North-west & 2 & 1370 & 181 & 13.2 & $11.5-15.1$ & 90.0 & 0.002 \\
\hline South-east & 7 & 4653 & 2174 & 46.7 & $45.3-48.2$ & 99.4 & 0.000 \\
\hline South-south & 10 & 8264 & 3953 & 47.8 & $46.8-48.9$ & 98.8 & 0.000 \\
\hline South-west & 15 & 16825 & 10972 & 65.2 & $64.5-65.9$ & 99.5 & 0.000 \\
\hline \multicolumn{8}{|l|}{ Study period } \\
\hline 1980-1991 & 4 & 8330 & 6736 & 80.9 & $80.0-81.7$ & 98.9 & 0.000 \\
\hline 1992-2003 & 7 & 7682 & 3932 & 51.2 & $50.1-52.3$ & 99.5 & 0.000 \\
\hline 2004-2014 & 30 & 18506 & 8233 & 44.5 & $43.8-45.2$ & 99.1 & 0.000 \\
\hline \multicolumn{8}{|l|}{ Sample size } \\
\hline $100-500$ & 23 & 6903 & 3375 & 48.9 & $47.7-50.1$ & 98.6 & 0.000 \\
\hline $501-1000$ & 6 & 4306 & 2176 & 50.5 & $49.3-52.0$ & 99.6 & 0.000 \\
\hline $1001-1500$ & 7 & 7996 & 5473 & 68.5 & $67.4-69.5$ & 99.6 & 0.000 \\
\hline$>1500$ & 5 & 15313 & 7877 & 51.4 & $50.7-52.2$ & 99.8 & 0.000 \\
\hline \multicolumn{8}{|l|}{ Study setting } \\
\hline Community-based & 9 & 4936 & 2914 & 59.0 & $57.7-60.4$ & 99.4 & 0.000 \\
\hline Hospital-based & 2 & 517 & 214 & 41.4 & $37.1-45.8$ & 99.1 & 0.000 \\
\hline School-based & 30 & 29065 & 15773 & 54.3 & $53.7-54.8$ & 99.5 & 0.000 \\
\hline \multicolumn{8}{|l|}{ SPSAG } \\
\hline SAC & 33 & 30319 & 16643 & 54.9 & $54.3-55.5$ & 99.5 & 0.000 \\
\hline PSAC & 8 & 4199 & 2258 & 53.8 & $52.3-55.3$ & 99.2 & 0.000 \\
\hline Overall & 41 & 34518 & 18901 & 54.8 & $54.2-55.3$ & 99.4 & 0.000 \\
\hline
\end{tabular}

Cl Confidence interval, $I^{2}$ Inverse variance index, Q-P Cochran's $P$-value, SPSAG School/Preschool-age groups, SAC School-aged children, $P S A C$

Preschool-aged children

(43.8\%) were the most prevalent species in the south-west while, hookworms (34.4\%) and S. stercoralis (10.9\%) recorded the highest prevalence in north-east and north-central regions respectively (Table 4). The highest prevalence of $A$. lumbricoides (46.6\%), hookworms (27.3\%) and T. trichiura (36.5\%) were observed among school-children while, S. stercoralis recorded the highest prevalence among children sampled within the community (Table 4).

\section{Regional distribution of eligible studies and RZs for STH infections}

The distribution of eligible studies is presented in Fig. 1. The highest numbers of studies were reported in the south-west region: 15 (46.3\%) and Osun State: seven (17.1\%). These were followed by the south-south region with $10(24.4 \%)$ and Ogun State with five (12.2\%). The south-west region recorded STH prevalence of $65.2 \%$ and is classified as HRZ while the rest of the regions recorded prevalence estimates ranging between 13.2 and $47.8 \%$ and are classified as LRZs (Fig. 8).

\section{Discussion}

The present study was designed to complement global efforts towards the control of neglected tropical diseases by providing useful epidemiological data that will aid their control. The study provides information on endemic species of STHs, their national and regional prevalence, their distribution in relation to regions, species, periods and settings as well as RZs. This data is essential because strategic anthelmintic control of STHs depends on community-based prevalence [28]. The findings will also (i) help in assessing successes of sporadic STHs control programmes in Nigeria which usually target children and (ii) provide information that will serve as a guide for targeted and cost-effective control which is a subject of debate globally [29-32].

The overall pooled prevalence estimate $(54.8 \%)$ observed in the present study is higher than the $24.1 \%$ [33] and 25.4\% [34] reported in Cameroon and Rwanda respectively. The finding is however within the range of 52.4-65.8\% reported from other sub-Saharan African countries $[35,36]$. These variations may be attributable 


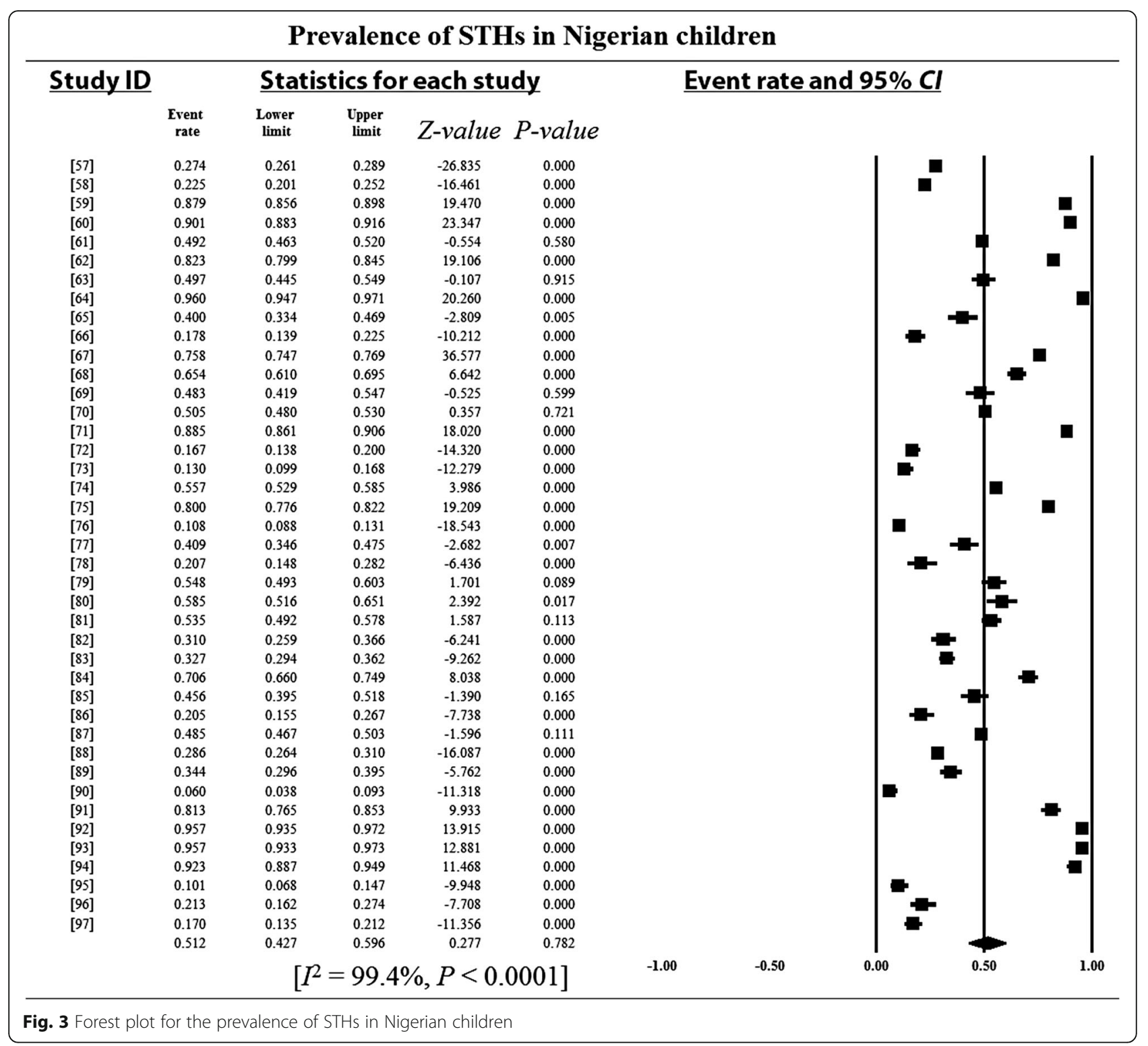

to differences in environmental factors such as temperature, humidity, rainfall [37] and soil moisture [38]. Other factors may be differences in levels of hygiene and sanitation, environmental contamination [39] as well as the specificity and sensitivity of the diagnostic methods employed by the individual studies.

The forested nature, the high level of rainfall, low humidity and temperature in south-western Nigeria [21] may explain the higher prevalence (65.2\%) of STH infections in the region. This suggests that this region may be the most endemic for STHs in Nigeria. Since cost-effective control requires knowledge of community prevalence for correct choice of anthelmintic strategy, this information may be useful for stakeholders in STHs control. The lower prevalence reported in the north-western region may be attributable to the extremely high temperatures in these regions
[21] which may not support environmental survival of eggs and larvae of these parasites [4].

The study revealed a $36.4 \%$ decline in the prevalence of STH infections within a period of twenty four years. This may not be unconnected with the global campaigns targeting eradication of neglected tropical diseases by year 2020 [40] resulting in increased efforts towards the control of STH infections in recent times. The higher number of studies reported during the most recent decade may be attributable to increased awareness of the public health threats posed by these parasites.

Studies carried out in communities other than schools and hospitals recorded the highest PPE probably due to the sporadic STHs control programmes in Nigeria which usually targets school and hospitalized children. Though there are scanty reports of STH infections among adults 


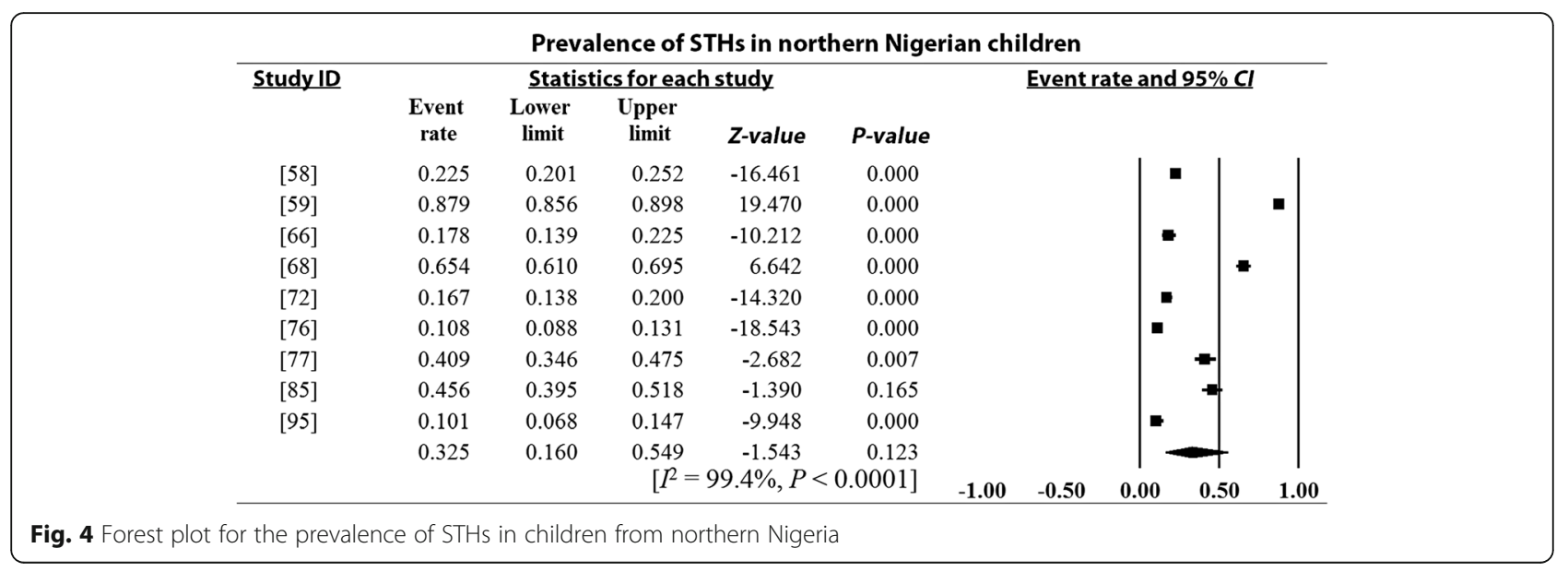

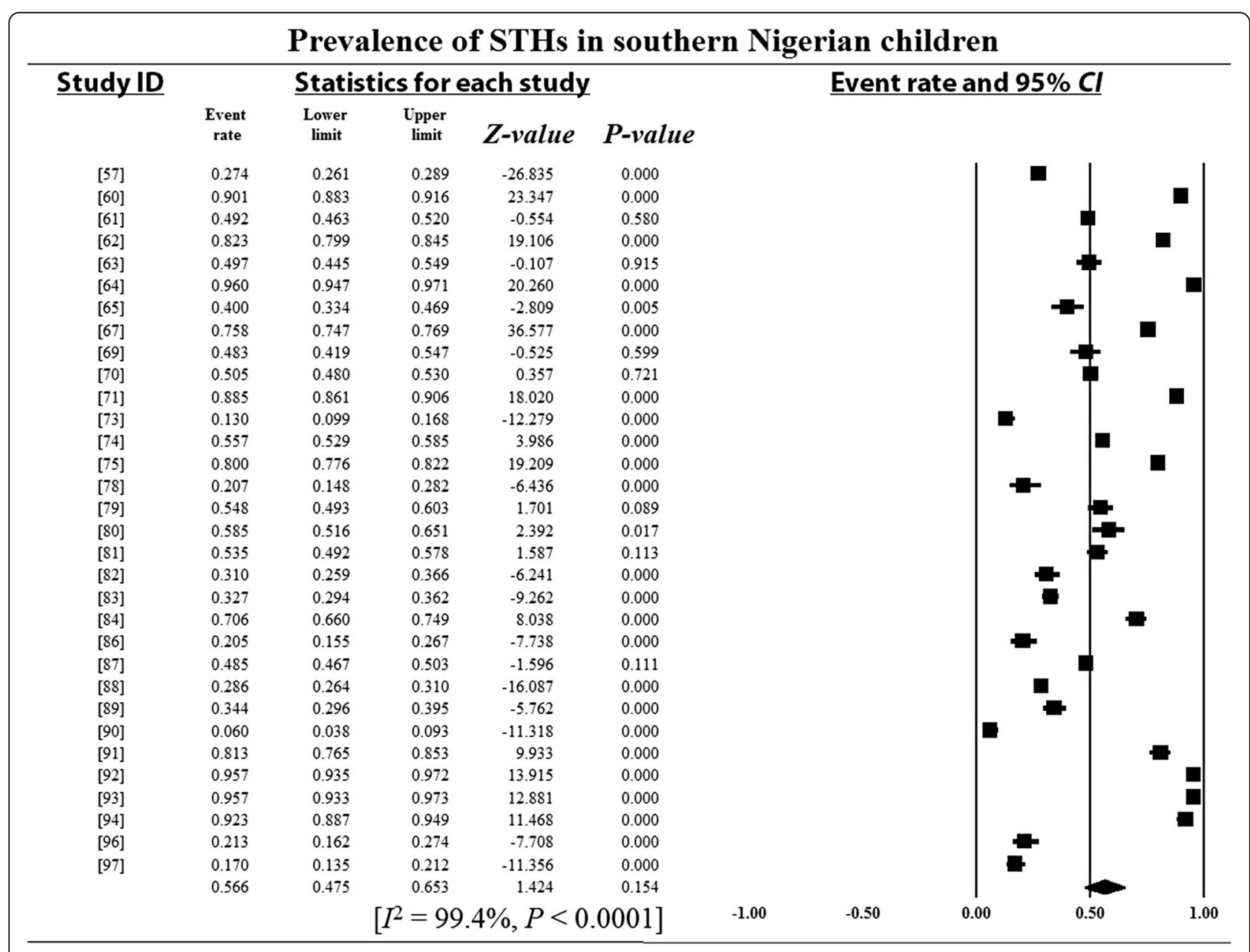

Fig. 5 Forest plot for the prevalence of STHs in children from southern Nigeria 


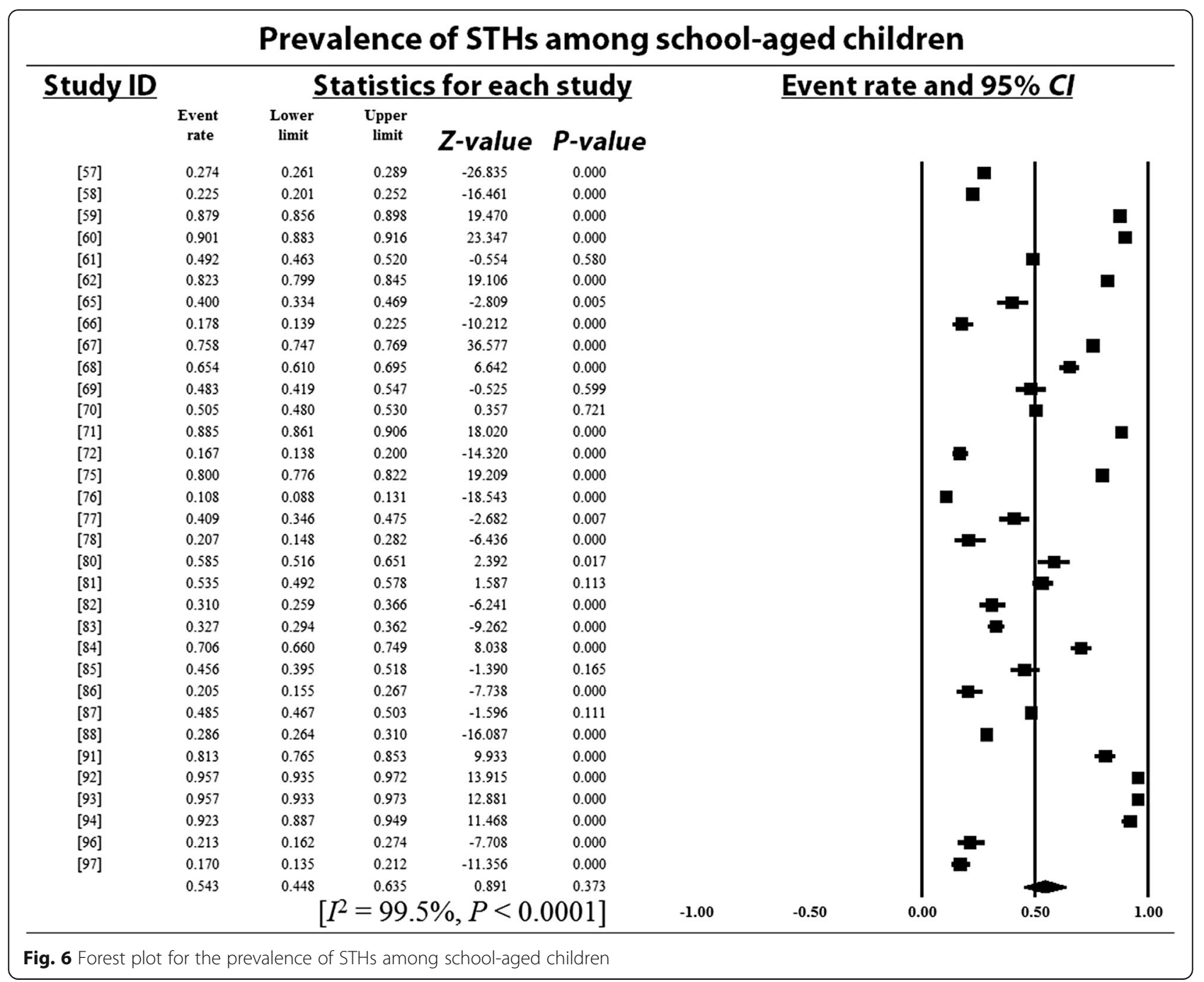

in Nigeria, the PPE reported in the present study is higher than the range of 9.4-28.6\% [41-43] documented among adults in Nigeria. Reports of STH infections in adults in Nigeria and other sub-Saharan African countries [44-46] suggest that the burden of these parasites is not restricted to children. These findings suggest the need for Nigeria to adopt the current WHO recommended strategy for the control of STH infections at community levels. This strategy involves prevalence-based targeted distribution of albendazole and mebendazole in both school and

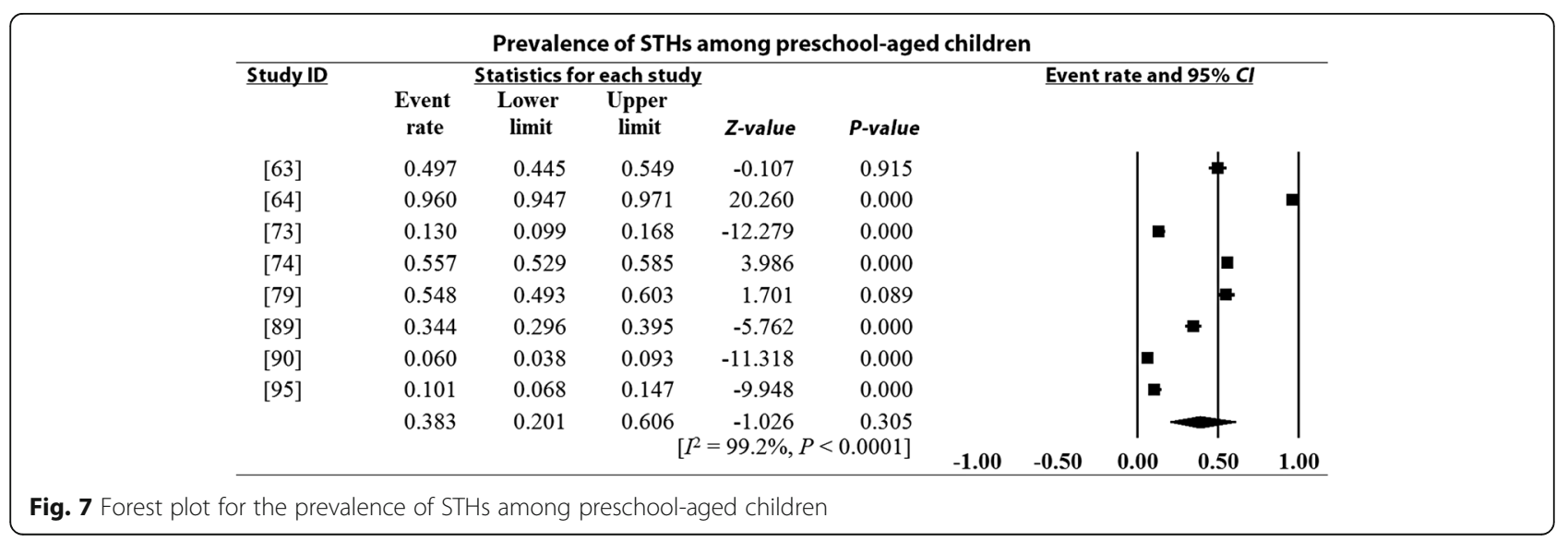


Table 3 Species-specific pooled prevalence estimates for STH infections

\begin{tabular}{|c|c|c|c|c|c|c|c|}
\hline \multirow[t]{2}{*}{ Parasites } & \multirow{2}{*}{$\begin{array}{l}\text { Number of } \\
\text { studies }\end{array}$} & \multicolumn{3}{|c|}{ Pooled prevalence estimates } & \multirow[t]{2}{*}{$95 \% \mathrm{Cl}$} & \multicolumn{2}{|c|}{ Heterogeneity } \\
\hline & & Sample size & Positives & Prevalence (\%) & & $\bar{P}(\%)$ & $\mathrm{Q}-\mathrm{P}$ \\
\hline Ascaris lumbricoides & 38 & 29177 & 13006 & 44.6 & $44.0-45.2$ & 99.4 & 0.000 \\
\hline Hookworms & 34 & 25634 & 5898 & 23.0 & $22.5-23.5$ & 99.5 & 0.000 \\
\hline Strongyloides stercoralis & 15 & 10581 & 364 & 3.4 & $3.1-3.8$ & 99.5 & 0.000 \\
\hline Trichuris trichiura & 31 & 23089 & 7373 & 31.9 & $31.3-32.5$ & 99.4 & 0.000 \\
\hline
\end{tabular}

STH Soil-transmitted helminths, $C$ C Confidence interval, $I^{2}$ Inverse variance index, Q-P Cochran's $P$-value

preschool-aged children as well as women of child bearing age [40].

The species of STHs reported in Nigerian children during the period under review are similar to those reported in other sub-Saharan African countries like Cameroon [47], Ethiopia [36], Kenya [48] and Uganda [49]. This finding shows that these parasites are still endemic in the region suggesting that extra efforts are required to achieve the WHO's goal of eradication in sub-Saharan Africa by 2020 .

A. lumbricoides was the most prevalent species of STHs reported during the period under review while, hookworms had the lowest prevalence in agreement with global data $[2,3,12]$. The high prevalence of $A$. lumbricoides observed by the present study may be attributable to high environmental contamination resulting from the large number of infected people [4], the durability of Ascaris eggs under varying environmental conditions [50], the high fecundity [51] as well as the sticky nature of the shell of Ascaris egg [52] which aids its attachment on human hands, fruits and vegetables.
South-western Nigeria recorded the highest PPE for $A$. lumbricoides (53.9\%) and T. trichiura (43.8\%) probably due to the forested nature, high rainfall, low humidity and temperature [21] in this region. The highest prevalence of hookworms in the north-eastern region may not be unconnected with the practice of inhabitants of the region walking barefoot $[5,6]$. Other possible factors responsible for the high prevalence of these species in the region may include poverty, inadequate sanitation, overcrowding and the consumption of unwashed fruits and vegetables [53].

The rainy season influences soil moisture. This in turn determines the survival of STH eggs and larvae in the environment. Public education on the high risk of acquiring infection during this season especially through the consumption of contaminated vegetables will be a good measure towards the control of these infections. Since this season is associated with high intensity of STH infections, MDA campaigns should be programmed to target the rainy season for effectiveness.

Though the sporadic control efforts in Nigeria usually target school-aged children, the present study revealed a similar prevalence between school and preschool-aged

Table 4 Pooled prevalence estimates for STH infections in relation to regions and study settings

\begin{tabular}{|c|c|c|c|c|c|c|c|c|}
\hline \multirow[b]{2}{*}{ Variables } & \multicolumn{2}{|c|}{ Ascaris lumbricoides } & \multicolumn{2}{|c|}{ Hookworms } & \multicolumn{2}{|c|}{ Strongyloides stercoralis } & \multicolumn{2}{|c|}{ Trichuris trichiura } \\
\hline & SSZ & Cases (\%) & SSZ & Cases (\%) & SSZ & Cases (\%) & SSZ & Cases (\%) \\
\hline \multicolumn{9}{|l|}{ Regions } \\
\hline North-central & 1935 & $596(30.8)$ & 2936 & $476(16.2)$ & 1387 & $151(10.9)$ & 955 & $308(32.3)$ \\
\hline North-east & 250 & $57(22.8)$ & 250 & $86(34.4)$ & 250 & $23(9.2)$ & 250 & $26(10.4)$ \\
\hline North-west & 1370 & $119(8.7)$ & 570 & $30(5.3)$ & 800 & $12(1.5)$ & 570 & $20(3.5)$ \\
\hline Total & 3555 & $772(21.7)$ & 3756 & $592(15.8)$ & 2437 & $186(7.6)$ & 1775 & $354(19.9)$ \\
\hline South-east & 3334 & $918(27.5)$ & 3334 & $898(26.9)$ & 2250 & $78(3.5)$ & 2850 & $335(11.8)$ \\
\hline South-south & 5297 & $2111(39.9)$ & 5157 & $848(16.4)$ & 2892 & $106(3.7)$ & 5297 & $1144(21.6)$ \\
\hline South-west & 17091 & $9205(53.9)$ & 11289 & 3549 (31.5) & 3002 & $34(1.1)$ & 12638 & $5540(43.8)$ \\
\hline Total & 25722 & $12234(47.6)$ & 19780 & 5295 (26.8) & 8144 & $218(2.7)$ & 20785 & 7019 (33.8) \\
\hline \multicolumn{9}{|l|}{ Study setting } \\
\hline Community & 4936 & $1828(37.0)$ & 4427 & $200(4.5)$ & 1969 & $99(5.0)$ & 4708 & $761(16.2)$ \\
\hline Hospital & 517 & $133(25.7)$ & 517 & $42(8.1)$ & 207 & $1(0.5)$ & 517 & $38(7.4)$ \\
\hline School & 23724 & 11045 (46.6) & 20690 & $5656(27.3)$ & 8405 & $321(3.8)$ & 17867 & $6517(36.5)$ \\
\hline Total & 29177 & 13006 (44.6) & 25634 & $5898(23.0)$ & 10581 & $421(4.0)$ & 23092 & 7316 (31.7) \\
\hline
\end{tabular}

SSZ Sample size 


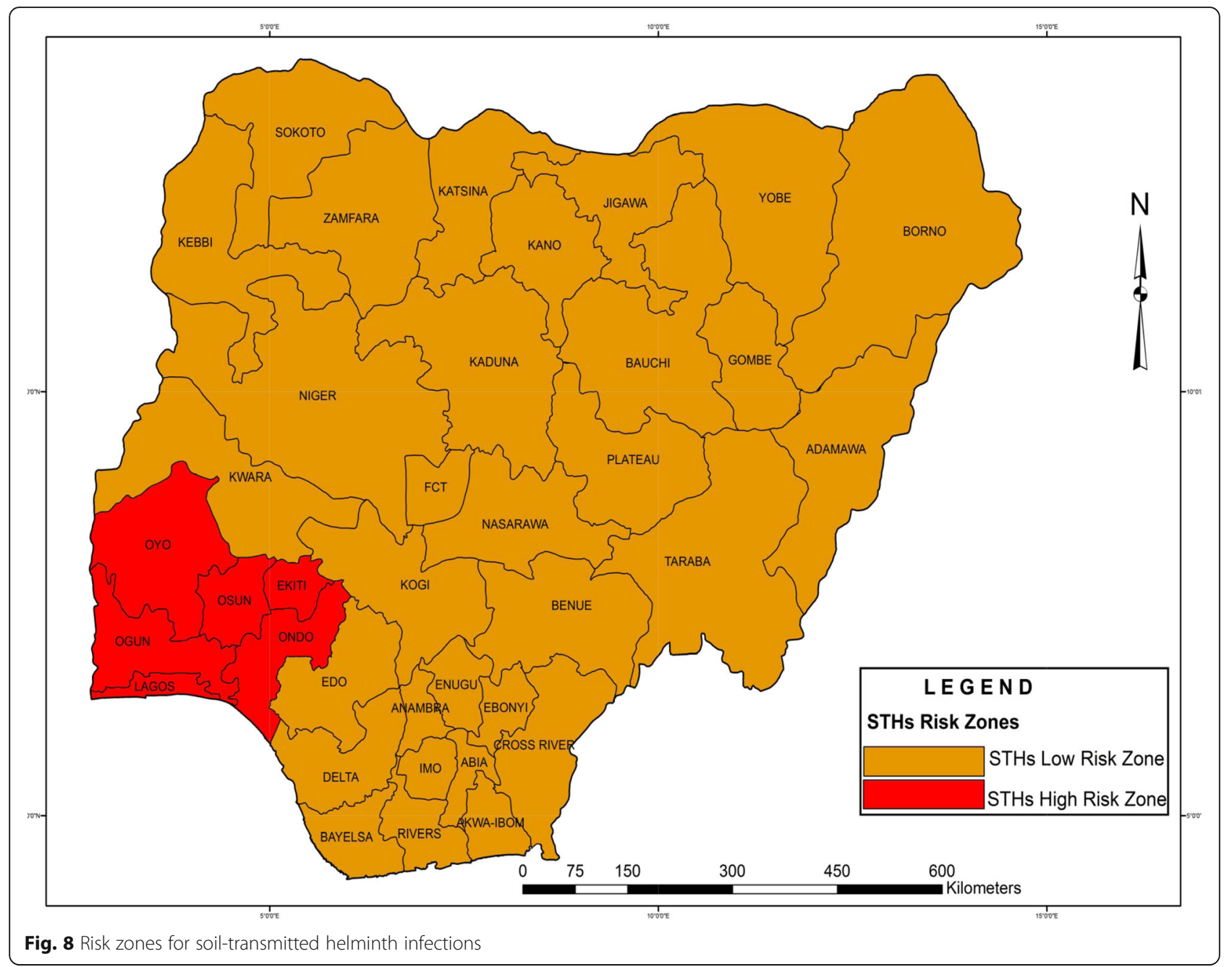

children indicating possible failures in these control programmes. It is envisaged that the nation will take advantage of the information provided on regional and national prevalence, distribution and RZs for STH infections to re-strategize on their control in Nigeria.

A recent study in Nigeria by Oluwole et al. [54] which utilized data produced by a large scale national survey conducted by the Ministry of Health among children aged 5-14 years across the country observed prevalence of > $50 \%$ for A. lumbricoides and hookworms and a range of $20.01-50.00 \%$ for $T$. trichiura in several locations within the south-western region. The same study showed that most locations in the north-central, north-eastern, north-western, south-eastern and south-south regions reported the range of $<1.00-20.00 \%$ while a few locations had prevalence range of $20.01-50.00 \%$. Their report supports the classification of the north-central, north-east, north-west, south-east and south-south as LRZs and south-west as HRZ by the present study. These two concurring reports suggest that the majority of Nigerian regions are LRZs for STH infections.
The idea behind the present study is to complement global efforts towards elimination of STH infections by 2020 as targeted by the WHO and the London declaration $[55,56]$. This finding will therefore be a guide for instituting national MDA programmes which classify communities into low risk (prevalence: $20 \%$ to $<50 \%$ ) and high risk (prevalence $\geq 50 \%$ ) and their respective treatment regimens. The present finding shows that the south-western region which has a PPE of $65.2 \%$ is a high risk community while the rest of the regions recorded PPEs ranging between 13.2 and $47.8 \%$ and are considered low risk communities. Based on the WHO guidelines for MDA, biannual albendazole or mebendazole treatment is recommended for people living in the south-west Nigeria (prevalence: $65.2 \%$ ) while single annual treatment is recommended for people living in the north-central, north-east, south-east and south-south Nigeria (prevalence: 45.6-47.8\%). For people living in the north-western region where prevalence was less than $20 \%(13.2 \%)$, improved sanitation, health education and a case-by-case handling of affected individuals [27] is 
recommended. Effective implementation of this programme which is highly cost effective will drastically reduce the burden of STH infections in Nigeria.

Despite the valuable data provided by this study, it is not devoid of limitations. Studies were reported from only 19 of the 36 states including the Federal Capital Territory. Studies were unevenly distributed across regions, study period and study settings. Other studies which would have added to our understanding of STHs situation in Nigeria were excluded for incomplete information. The study revealed high heterogeneity among studies which may be due to variations in study designs, methodologies, sample populations and methods of diagnosis employed by the various studies.

\section{Conclusions}

STH infections are highly prevalent and well distributed across Nigeria and within community, hospital and school settings. A. lumbricoides was the most prevalent of the STH species. The south-west is a HRZ for STH infections while the rest of the regions are LRZs. The adoption of the current WHO recommended strategy for the control of STH infections at community levels which involves prevalence-based targeted distribution of albendazole and mebendazole among school and preschool-aged children, women of child-bearing age and adults in RZs in Nigeria will reduce the menace pose by these parasites.

\section{Additional files}

Additional file 1: Multilingual abstracts in the five official working languages of the United Nations. (PDF $234 \mathrm{~kb}$ )

Additional file 2: Preferred Reporting Items for Systematic Reviews and Meta-Analyses (PRISMA) checklist. (DOC $62 \mathrm{~kb}$ )

Additional file 3: Forest plot for the prevalence of STHs in children sampled within communities. (DOCX $77 \mathrm{~kb}$ )

Additional file 4: Forest plot for the prevalence of STHs in children sampled within schools. (DOCX $95 \mathrm{~kb}$ )

Additional file 5: Forest plot for the prevalence of STHs in children sampled within hospitals. (DOCX $50 \mathrm{~kb}$ )

\section{Abbreviations}

AJOL: African Journals OnLine; Cl: Confidence interval; df: Degree of freedom;

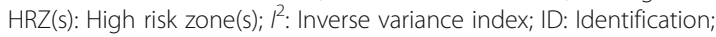
LRZ(s): Low risk zone(s); MDA: Mass drug administration; NCR: North-central region; NER: North-east region; NWR: North-west region; PPE(s): Pooled prevalence estimate(s); PRISMA: Preferred Reporting Items for Systematic Reviews and Meta-Analyses; PSAC: Preschool-aged children; Q: Cochran's heterogeneity statistics; Q-p: Cochran's P-value; RZ(s): Risk zone(s); SAC: School-aged children; SER: South-east region; SPSAG: School/Preschoolage groups; SSR: South-south region; SSZ: Sample size; STH: Soil-transmitted helminths; SWR: South-west region; WHO: World Health Organization

\section{Acknowledgements}

The author is grateful to the Editor-In-Chief of the Nigerian Journal of Parasitology for making available some of the articles included in the meta-analysis and to Mrs. Juliana Tije for helping in literature search.

\section{Availability of data and materials}

The data supporting the conclusion of this article are all included within the article and Additional files 2, 3, 4 and 5.

\section{Authors' contributions}

SNK: Conceived and designed the study, conducted comprehensive literature search, screened literatures, extracted data, carried out statistical and metaanalysis, wrote the paper and approved the final version of the manuscript.

Ethics approval and consent to participate

Not applicable.

\section{Consent for publication}

Not applicable.

\section{Competing interests}

The author declares that he has no competing interest

Received: 25 September 2017 Accepted: 14 June 2018

Published online: 09 July 2018

\section{References}

1. Mascarini-Serra L. Prevention of soil-transmitted helminth infection. J Glob Infect Dis. 2011;3(Suppl 2):175-82.

2. Hotez PJ, Fenwick A, Savioli L, Molyneux DH. Rescuing the bottom billion through control of neglected tropical diseases. Lancet. 2009:373(Suppl 9674):1570-5.

3. De Silva NR, Brooker S, Hotez PZ, Montresor A, Engels D, Savioli L. Soiltransmitted helminth infections: updating the global picture. Trends Parasitol. 2003;19(Suppl 12):547-51.

4. Brooker S, Clements ACA, Bundy DAP. Global epidemiology, ecology and control of soil-transmitted helminth infections. Adv Parasitol. 2006;62:221-61.

5. Vandemark LM, Jia TW, Zhou XN. Social science implications for control of helminth infections in Southeast Asia. Adv Parasitol. 2010;73:137-70.

6. Alemu A, Atnafu A, Addis Z, Shiferaw Y, Teklu T, Mathewos B, et al. Soiltransmitted helminths and Schistosoma mansoni infections among school children in Zarima town, northwest Ethiopia. BMC Infect Dis. 2011;11(189):7. http://www.biomedcentral.com/1471-2334/11/189.

7. Ostan I, Kilimcioglu AA, Girginkardesler N, Ozyurt BC, Limoncu ME, Ok UZ. Health inequities: lower socio-economic conditions and higher incidences of intestinal parasites. BMC Pub Health. 2007;7(342):8. https://doi.org/10. 1186/1471-2458-7-342.

8. De Silva NR, Guyatt HL, Bundy DA. Morbidity and mortality due to Ascarisinduced intestinal obstruction. Trans R Soc Trop Med Hyg. 1997;91:31-6.

9. Galvani AP. Age-dependent epidemiological patterns and strain diversity in helminth parasites. J Parasitol. 2005;91(Suppl 1):24-30.

10. Despommier D. Toxocariasis: clinical aspects, epidemiology, medica ecology, and molecular aspects. Clin Microbiol Rev. 2003;6:265-72.

11. Fisher M. Toxocara cati: an underestimated zoonotic agent. Trends Parasitol. 2003;19:167-70.

12. Pullan R, Smith J, Jasrasaria R, Brooker S. Global numbers of infection and disease burden of soil transmitted helminth infections in 2010. Parasit Vectors. 2014;7(37):19. https://doi.org/10.1186/1756-3305-7-37.

13. Albonico M, Montresor A, Crompton DW, Savioli L. Intervention for the control of soil-transmitted helminthiasis in the community. Adv Parasitol. 2006;61:311-48.

14. Obiamiwe BA. The pattern of parasitic infections in human gut at the specialist hospital, Benin City, Nigeria. Ann Trop Med Parasitol. 1977;71:35-43.

15. Adeyeba OA, Dipeolu OO. A survey of gastrointestinal parasites in a local government area of south-west Nigeria. Intern J Zoon. 1984;11:105-10.

16. Alakija W. Prevalence of intestinal parasitic disease agents in stools of people in a rural area of Nigeria. Ann Trop Med Parasitol. 1986;80:545-7.

17. Udonsi JK, Behnke JM, Gilbert FS. Analysis of the prevalence of infection and associations between human gastrointestinal nematodes among different age classes living in the urban and suburban communities of Port Harcourt, Nigeria. J Helminthol. 1998;70:75-84.

18. Nwaorgu OC, Okeibunor J, Madu E, Amazigo U, Onyegegbu N, Evans D. A school-based schistosomiasis and intestinal helminthiasis control programme in Nigeria: acceptability to community members. Trop Med Int Health. 1998;3:842-9.

19. Odogwu SE, Ramamurthy NK, Kabatereine NB, Kazibwe F, Tukahebwa E, Webster JP, et al. Intestinal schistosomiasis in infants (3 years of age) along the Ugandan shoreline of Lake Victoria. Ann Trop Med Parasitol. 2006;100: 315-26. 
20. Bethony J, Brooker S, Albonico M, Geiger SM, Loukas A, Diemert D, et al. Soil-transmitted helminth infections: ascariasis, trichuriasis, and hookworm. Lancet. 2006;367:1521-32.

21. Iloeje NP. A new geography of Nigeria. New revised ed. Nigeria: Longman; 2001.

22. Moher D, Liberati A, Tetzlaff J, Altman DG, The PRISMA group. Preferred reporting items for systematic reviews and meta-analyses: the PRISMA statement. PLoS Med. 2009;6(Suppl 7):e1000097.

23. Wells GA, Shea B, O'Connel D, Peterson J, Welch V, Losos M, et al. The Newcastle-Ottawa scale (NOS) for assessing the quality of nonrandomised studies in meta-analyses. Appl Eng Agric. 2014;18(6):727-34

24. Higgins JPT, Green S. Cochrane handbook for systematic reviews of interventions version 5.1.0 (updated march 2011). Cochrane Collaboration. 2011. Available from www.handbook.cochrane.org

25. Hedges LV, Vevea JL. Fixed- and random-effects models in meta-analysis. Psychol Methods. 1998;3:486-504.

26. Higgins JP, Thompson SG. Quantifying heterogeneity in a meta-analysis. Stat Methods. 2002;21:1539-58.

27. World Health Organization. Preventive chemotherapy in human helminthiasis: coordinated use of anthelmintic drugs in control interventions: a manual for health professionals and programme managers. Geneva: World Health Organization press; 2006.

28. World Health Organization. Soil-transmitted helminthiases: number of children treated in 2010. Week Epidemiol Rec. 2013;87:225-32.

29. Guyatt $\mathrm{H}$. The cost of delivering and sustaining a control programme for schistosomiasis and soil-transmitted helminthiasis. Acta Trop. 2003;86(Suppl 2-3):267-74.

30. Sinuon M, Tsuyuoka R, Socheat D, Montresor A, Palmer K. Financial costs of deworming children in all primary schools in Cambodia. Tran R Soc Trop Med Hyg. 2005;99(Suppl 9):664-8.

31. Hall A, Horton S, de Silva N. The costs and cost-effectiveness of mass treatment for intestinal nematode worm infections using different treatment thresholds. PLoS Neg Trop Dis. 2009;3(Suppl 3):e402.

32. Turner HC, Truscott JE, Hollingsworth TD, Bettis AA, Brooker SJ, Anderson RM. Cost and cost-effectiveness of soil-transmitted helminth treatment programmes: systematic review and research needs. Parasit Vectors. 2015; 8(355):23. https://doi.org/10.1186/s13071-015-0885-3.

33. Tchuem-Tchuente LA, Kamwa-Ngassam Rl, Sumo L, Ngassam P, DongmoNoumedem C, Nzu DD, et al. Mapping of schistosomiasis and soiltransmitted helminthiasis in the regions of Centre, East and West Cameroon. PLoS Neg Trop Dis. 2012;6(Suppl 3):e1553.

34. Staudacher $\mathrm{O}$, Heimer J, Steiner F, Kayonga $\mathrm{Y}$, Havugimana JM, Ignatius $\mathrm{R}$, et al. Soil-transmitted helminths in southern highland Rwanda: associated factors and effectiveness of school-based preventive chemotherapy. Trop Med Int Hlth. 2014;19(Suppl 7):812-24.

35. Center for Infectious Diseases Control Rwanda. National prevalence survey on soil-transmitted helminths and schistosomiasis. Kigali: Centre for Infectious Diseases Control Rwanda Access Project and National Reference Laboratory; 2008.

36. Tadege B, Shimelis T. Infections with Schistosoma mansoni and geohelminths among school children dwelling along the shore of the Lake Hawassa, southern Ethiopia. PLoS One. 2017;12(Suppl 7):e0181547.

37. Steinmann P, Zhou XN, Li YL, Li HJ, Chen SR, Yang Z, et al. Helminth infections and risk factor analysis among residents in Eryuan county, Yunnan province, China. Acta Trop. 2007;104:38-51.

38. Cundill B, Alexander N, Bethony JM, Diemert D, Pullan RL, Brooker S. Rates and intensity of re-infection with human helminths after treatment and the influence of individual, household, and environmental factors in a Brazilian community. Parasitology. 2011;138:1406-16.

39. Lee AC, Schantz PM, Kazacos KR, Montgomery SP, Bowman DD. Epidemiologic and zoonotic aspects of ascarid infections in dogs and cats. Trends Parasitol. 2010;26(Suppl 4):155-61.

40. World Health Organization. Helminth control in school-age children: a guide for managers of control programmes. Geneva: World Health Organization; 2001. Available at: whqlibdoc.who.int/publications/2011/9789241548267_eng.pdf

41. Egwunyenga AO, Ajayi JA, Nmorsi OPG, Duhlinska-Popova DD. Plasmodium/ intestinal helminth co-infections among pregnant Nigerian women. Mem Inst Oswaldo Cruz. 2001;96(Suppl 8):1055-9.

42. Bassey EB, Asor JE. Endo-parasitic infections among pregnant women and HIVsero-positive patients attending clinics in Abuja, Nigeria. Nig J Parasitol. 2009;30(Suppl 2):138-41.
43. Wokem GN, Onosakpondme EO. Soil transmitted helminthiasis in Sapele local government, Delta state. Nig J Parasitol. 2014;35(Suppl 1-2):143-8.

44. Chami GF, Fenwick A, Bulte E, Kontoleon AA, Kabatereine NB, Tukahebwa EM, et al. Influence of Schistosoma mansoni and hookworm infection intensities on anaemia in Ugandan villages. PLoS Negl Trop Dis. 2015;9(Suppl 10):e0004193.

45. Siza JE, Kaatano GM, Chai J, Eom KS, Rim H, Yong T, et al. Prevalence of schistosomes and soil-transmitted helminths and morbidity associated with schistosomiasis among adult population in Lake Victoria Basin, Tanzania. Korean J Parasitol. 2015;53(Suppl 5):525-33.

46. Masaku J, Mutungi F, Gichuki PM, Okoyo C, Njomo DW, Njenga SM. High prevalence of helminth infections and associated risk factors among adults living in a rural setting, Central Kenya: a cross-sectional study. Trop Med HIth. 2017;45(Suppl 15):9. https://doi.org/10.1186/s41182-017-0055-8.

47. Tchuem-Tchuente LA, Behnke JM, Gilbert FS, Southgate VR, Vercruysse J. Polyparasitism with Schistosoma haematobium and soil-transmitted helminth infections among school children in Loum, Cameroon. Trop Med Intern Hlth. 2003;8(Suppl 11):975-86.

48. Kepha S, Nuwaha F, Nikolay B, Gichuki P, Edwards T, Allen E, et al. Epidemiology of co-infection with soil transmitted helminths and Plasmodium falciparum among school children in Bumula District in western Kenya. Parasit Vectors. 2015;8(314):10. https://doi.org/10.1186/ s13071-015-0891-5.

49. Kabatereine NB, Tukahebwa EM, Kazibwe F, Twa-Twa JM, Barenzi JF, Zaramba S, et al. Soil-transmitted helminthiasis in Uganda: epidemiology and cost of control. Trop Med Intern HIth. 2005;10(11):1187-9.

50. O'Lorcain P, Holland CV. The public health importance of Ascaris lumbricoides. Parasitology. 2000;121:S51-71.

51. Hall A, Holland C. Geographical variation in Ascaris lumbricoides fecundity and its implications for helminth control. Parasitol Today. 2000;16(12):540-4.

52. Quilès F, Balandier JY, Capizzi-Banas S. In situ characterisation of a microorganism surface by Raman microspectroscopy: the shell of Ascaris eggs. Analytical Bioanalytical Chem. 2006;386(Suppl 2):249-55.

53. World Health Organization. Prevention and control of schistosomiasis and soil transmitted helminthiasis, WHO technical report series 912: i-vi. Geneva: World Health Organization; 2002.

54. Oluwole AS, Ekpo UF, Karagiannis-Voules D-A, Abe EM, Olamiju FO, Isiyaku S, et al. Bayesian geo-statistical model-based estimates of soil-transmitted helminth infection in Nigeria, including annual deworming requirements. PLoS Negl Trop Dis. 2015;9(Suppl 4):e0003740.

55. World Health Organization. Accelerating work to overcome the global impact of neglected tropical diseases: a roadmap for implementation http:// www.who.int/neglected_diseases/NTD_RoadMap_2012_Fullversion.pdf. Accessed Nov 212017.

56. Uniting to Combat Neglected Tropical Diseases London declaration on neglected tropical diseases Ending the neglect and reaching 2020 goals. 2013. http://unitingtocombatntds.org/. Accessed 21 Nov 2017.

57. Abah AE, Arene FOI. Status of intestinal parasitic infections among primary school children in rivers state, Nigeria. J Parasitol Res. 2015;2015:7. https:// doi.org/10.1155/2015/937096.

58. Adedoja A, Tijani BD, Akanbi AA, Ojurongbe TA, Adeyeba OA, Ojurongbe O. Co-endemicity of Plasmodium falciparum and intestinal helminth infections in school age children in rural communities of Kwara state Nigeria. PLoS Neg Trop Dis. 2015;9(Suppl 7):e0003940.

59. Adedoyin MA, Awogun IA, Juergensen T. Prevalence of intestinal parasitoses in relationship to diarrhoea among children in Ilorin. West Afr J Med. 1990; 9(Suppl 2):83-8.

60. Adenusi AA, Ogunyomi EOA. Relative prevalence of the human hookworm species, Necator americanus and Ancylostoma duodenale in an urban community in Ogun state. Nigeria Afr J Biotech. 2003;2(Suppl 11):470-3.

61. Adeoye GO, Osayemi CO, Oteniya O, Onymekeihia SO. Epidemiological studies of helminths and malaria among children in Lagos, Nigeria. Pakistan J Biol Sci. 2007;10(Suppl 13):2208-12.

62. Agbolade OM, Agu NC, Adesanya OO, Odejayi AO, Adigun AA, Adesanlu EB, et al. Intestinal helminthiases and schistosomiasis among school children in an urban Centre and some rural communities in Southwest Nigeria. Korean J Parasitol. 2007:45(Suppl 3):233-8.

63. Anah MU, Ikpeme OE, Etuk IS, Yong KE, Ibanga I, Asuquo BE. Worm infestation and anaemia among pre-school children of peasant farmers in Calabar, Nigeria. Nig J Clin Pract. 2008;11(Suppl 3):220-4.

64. Arene FO, Akabogu OA. Intestinal parasitic infections in pre-school children in the Niger Delta. J Hyg Epidemiol Microbiol Immunol. 1986;30(Suppl 1):99-102. 
65. Aribodor DN, Okechukwu PA, Eneanya OA, Etaga HO. Prevalence and associated risk factors of intestinal helminth infections among 5-14 year olds in Akpo community, Anambra state, Nigeria. Nig J Parasitol. 2013; 34(Suppl 2):107-11.

66. Babamale OA, Ugbomoiko US, Nurudeen SA, Rukayat OH. Hookworm infections among the school-aged children in Okuta community, Kwara state, Nigeria. Nig J Parasitol. 2015;36(Suppl 1):33-7.

67. Ejezie GC. The parasitic diseases of school children in Lagos state, Nigeria. Acta Trop. 1981;38(Suppl 1):79-84.

68. Eke SS, Omalu ICJ, Otuu CA, Salihu IM, Udeogu VO, Hassan SC, et al. Prevalence of geo-helminths in soil and primary school children in panda development area, Karu local government area, Nasarawa state, Nigeria. Nig J Parasitol. 2015;36(Suppl 2):91-5.

69. Ekpo UF, Odoemene SN, Mafiana CF, Sam-Wobo SO. Helminthiasis and hygiene conditions of schools in Ikenne, Ogun state, Nigeria. PLoS Neg Trop Dis. 2008;2(Suppl 1):e146.

70. Enekwechi LC, Azubike CN. Survey of the prevalence of intestinal parasites in children of primary school age. West Afr J Med. 1994;13(Suppl 4):227-30.

71. Holland CV, Asaolu SO, Crompton DWT, Stoddart RC, Macdonald R, Torimiro SEA. The epidemiology of Ascaris lumbricoides and other soil-transmitted helminths in primary school children from Ile-lfe, Nigeria. Parasitology. 1989; 99(Suppl 2):275-85.

72. Ihesiulor GU, Kashibu E, Azeez-Akande O, Imoru M. Helminths of gastrointestinal tract among children in Kano, northern Nigeria. Asian J Biol Life Sci. 2013;2(Suppl 2):122-6.

73. Kirwan P, Asaolu SO, Abiona TC, Jackson AL, Smith HV, Holland CV. Soiltransmitted helminth infections in Nigerian children aged 0-25 months. J Helminthol. 2009;83(Suppl 3):261-6.

74. Kirwan P, Asaolu SO, Molloy SF, Abiona TC, Jackson AL, Holland CV. Patterns of soil-transmitted helminth infections and impact of four-monthly albendazole treatments in pre-school children from semi-urban communities in Nigeria: a double-blind placebo-controlled randomised trial. BMC Infect Dis. 2009;9(20):12. https://doi.org/10.1186/1471-2334-9-20.

75. Mordi RM, Evelyn UE, Fredrick OA, Okafor FU. Intestinal nematode infections among school children in Aniocha south local government area of Delta state, Nigeria. Nig J Parasitol. 2011;32(Suppl 2):203-7.

76. Nock HI, Duniya D, Galadima M. Geo-helminth eggs in the soil and stool of pupils of some primary schools in Samaru, Zaria, Nigeria. Nig J Parasitol. 2003;24:115-22

77. Nwalorzie C, Onyenakazi SC, Ogwu SO, Okafor AN. Predictors of intestinal helminthic infections among school children in Gwagwalada, Abuja, Nigeria. Nig J Med. 2006;24(Suppl 3):233-41.

78. Nwaneri DU, Omuemu VO. Intestinal helminthiasis and nutritional status of children living in orphanages in Benin City, Nigeria. Nig J Clin Pract. 2013; 16(Suppl 2):243-8.

79. Nwaneri DU, Ibadin MO, Oforwe GE, Sadoh AE. Intestinal helminthiasis in children with chronic neurological disorders in Benin City, Nigeria: intensity and behavioural risk factors. Wld J Pediat. 2013;9(Suppl 2):152-7.

80. Nzeako SO, Nwaimo NC, Kafaru OJ, Onoja H. Nematode parasitemia in school aged children in Sapele, Delta state, Nigeria. Nig J Parasitol. 2013; 34(Suppl 2):129-33.

81. Obiukwu MO, Umeanaeto PU, Eneanya Cl, Nwaorgu GO. Prevalence of gastro-intestinal helminths in school children in Mbaukwu, Anambra state, Nigeria. Nig J Parasitol. 2008;29(Suppl 1):15-9.

82. Odinaka KK, Nwolisa EC, Mbanefo F, Iheakaram AC, Okolo S. Prevalence and pattern of soil-transmitted helminthic infections among primary school children in a rural community in Imo state, Nigeria. J Trop Med. 2015;2015:4. https://doi.org/10.1155/2015/349439.

83. Oninla SO, Owa JA, Onayade AA, Taiwo O. Intestinal helminthiases among rural and urban school children in South-Western Nigeria. Ann Trop Med Parasitol. 2007;101(Suppl 8):705-13.

84. Opara KN, Udoidung NI, Opara DC, Okon OE, Edosomwan EU, Udoh AJ. The impact of intestinal parasitic infections on the nutritional status of rural and urban school-aged children in Nigeria. Intern J MCH AIDS. 2012;1(Suppl 1):73-82.

85. Pukuma SM, Sale M. Prevalence of gastrointestinal helminth infections among children of Vunoklang primary school in Moderei Ward of Girei local government of area of Adamawa state, Nigeria. Nig J Parasitol. 2006;27(Suppl 1):73-5.

86. Rwang PG, Effiom OE, Ukah SU, Matur BM. The prevalence of Ascaris and hookworm infections among school children in Obehie, Ukwa-west local government area, Abia state, Nigeria. Nig J Parasitol. 2014;35(Suppl 1-2):65-9.
87. Sam-Wobo SO, Mafiana CF, Idowu AB. Re-infection patterns of ascariasis among school children in Ogun State, Nigeria. Nig J Parasitol. 2004; 25(Suppl 1):7-13.

88. Sam-Wobo SO, Mafiana CF, Agwuegbo S, Adebanji AO, Agbeyangi O, Idowu OA. Incidence of Ascaris infection among primary school children in Ogun State, Nigeria: A generalised linear model approach. Nig J Parasitol. 2008;29(Suppl 1):32-7.

89. Sowemimo OA, Asaolu SO. Current status of soil-transmitted helminthiases among pre-school and school-aged children from lle-lfe, Osun state, Nigeria. J Helminthol. 2011;85:234-8.

90. Tinuade O, John O, Saheed O, Oyeku O, Fidelis N, Olabisi D. Parasitic aetiology of childhood diarrhoea. Indian J Pediat. 2006;73(Suppl 12):1081-4.

91. Ugbogu OC, Asogu GO. Prevalence of intestinal parasites amongst school children in Unwana community, Afikpo, Ebonyi state, Nigeria. Nig J Parasitol. 2013;34(Suppl 2):69-71.

92. Ugbomoiko US, Onajole AT, Edungbola LD. Prevalence and intensity of geohelminth infections in Oba-lle community of Osun state, Nigeria. Nig J Parasitol. 2006;27(Suppl 1):62-7.

93. Ugbomoiko US, Dalumo V, Danladi YK, Heukelbach J, Ofoezie IE. Concurrent urinary and intestinal schistosomiasis and intestinal helminthic infections in school-children in Ilobu, South-Western Nigeria. Acta Trop. 2012;123:16-21.

94. Ukpai OM, Ugwa CD. The prevalence of gastro-intestinal tract parasites in primary school children in Ikwuano local government area of Abia state, Nigeria. Nig J Parasitol. 2003;24(Suppl 1):129-36.

95. Utume LN, Umeh EU, Onekutu A, Omudu EA. Intestinal protozoan and helminthic diarrheal infections in children under five years old in Agasha, Benue state, north-central Nigeria. Nig J Parasitol. 2015;36(Suppl 2):119-25.

96. Wagbatsoma VA, Aisien MS. Helminthiasis in selected children seen at the University of Benin Teaching Hospital (UBTH), Benin City, Nigeria. Nig Postgraduate Med J. 2005;12(Suppl 1):23-7.

97. Wokem GN, Wokem VC. Epidemiology of intestinal helminthiasis among school children attending public and private primary schools in Port Harcourt, rivers state, Nigeria. Nig J Parasitol. 2014;35(Suppl 1-2):41-5.

\section{Ready to submit your research? Choose BMC and benefit from:}

- fast, convenient online submission

- thorough peer review by experienced researchers in your field

- rapid publication on acceptance

- support for research data, including large and complex data types

- gold Open Access which fosters wider collaboration and increased citations

- maximum visibility for your research: over $100 \mathrm{M}$ website views per year

At BMC, research is always in progress.

Learn more biomedcentral.com/submissions 